checking absenteeism and 'column-dodging' .It is management's job both to select the right foremen (which includes providing the right incentives to their recruitment) and to see that their span of control is suitable.

The importance of intermediate management is one of the obvious lessons of this, as of other related inquiries. In order that respect and trust may be generated, it is necessary both that intermediate positions be filled by men of ability and character and that the system within which they work should allow decisions to be made quickly, unequivocally and comprehensibly at the appropriate point. Both the choice and appointment of subordinates and the devising of the structure of authority is the responsibility of top management. It is for top management to devise, and for intermediate management to operate, that system of communications with which the small unit can dispense but which must grow more complex, with increasing size, if instructions are to be understood and morale-destroying misunderstandings are to be avoided. The need of such a system should not be a permanent and inherent handicap of size.

The real difficulty of the big organization, however, springs from the calls that it makes on managerial ability ; these outrun the supply of adequately trained managers. The small unit can get on with managers who are competent technicians and reasonably forceful, fair-minded and intelligent characters; the large unit needs specialists, and these, in the numbers required, simply do not exist. The lost-time rates of the large-scale units, and the inadequate morale of which these are largely the symptom and index, reflect this deficiency. To overcome it is an essential step both towards saving the material waste caused by lost time and towards creating a humanly satisfying climate in large-scale industry.

T. H. HAWKINS

\section{CONTROL OF PUBLIC EXPENDITURE ON SCIENTIFIC PROJECTS}

$\mathrm{T}$

$\mathrm{HE}$ third report from the Committee of Public Accounts for the Session 1956-57 has recently been issued*. Reference is made in it to the Treasury Minute of January 31, 1957, rejecting the Com mittee's recommendation that the Comptroller and Auditor-General should have access to such papers and records of the University Grants Committee as related to non-recurrent grants to the universities; and the Committee expresses appreciation of the fact that, by ensuring that in future the accounting officer is better informed as to the projects on which voted money is being spent and by making much additional information available to the Comptroller and Auditor-General, the Treasury has gone some way towards meeting the Committee's wishes. The Committee recommends that the new arrangements proposed by the Treasury should be given a trial over a period of three years, when the matter might be further reviewed.

Among other matters discussed in this report is the grant by the Department of Scientific and Industrial Research to the University of Manchester towards the construction of the radio-telescope at

* Third Report from the Committee of Public Accounts, Session 1956-57. Pp. 36. (London: H.M. Stationery Office, 1957.) 1s. net.
Jodrell Bank. Originally estimated in March 1952 to cost $£ 335,450$, including four years running expenses, the cost had risen in May 1953 to $£ 439,616$, towards which the Nuffield Foundation had agreed to contribute $£ 200,000$ and the Department $£ 230,000$, subject to some conditions relating to financial control, including the requirement that the Department should be consulted if any substantial variation from the expenditure detailed in the approved estimate became necessary. The University entrusted the design work and supervision of construction of the telescope to a firm of consultant engineers under an agreement which provided inter alia that prior approval of the University should be obtained for any serious modification of the design or in the cost of the work and for any large variations of contracts, which were to be let only with the written authority of the University. Further rises in costs before the work was completed were expected, and in November 1954 the University notified the Department that the May 1953 estimate might be exceeded by $£ 50,000$. In October 1955, however, the University informed the Department orally that the increase was likely to be $£ 240,000$ and that it had become clear that the design had been changed substantially without the University's approval. A committee of inquiry was set up jointly by the Department, the Nuffield Foundation and the University, and this committee, which reported on March 15, 1956, recorded what the Department described to the Treasury as a very unsatisfactory position as between the University and the consultants. Nevertheless, the Department considered it imperative that the telescope should be completed and recommended a further grant of one-half the cost above the $£ 430,000$ already provided, subject to a limit of $£ 130,000$.

The Department informed the Committee of Public Accounts that normally it stated the terms under which the grant would be given to a university, and then trusted the university to expend the grant in a reasonably competent manner: the Department would not intervene in negotiations between a university and its contractors. It was also stated in evidence that the engineering consultant changed the design without the concurrence of the University of Manchester, introducing new structural features which materially increased the complexity and cost; but Prof. A. C. B. Lovell, who was primarily responsible for the outline design and lived on the spot, was apparently not even consulted. The Treasury also agreed that expenditure on the telescope had not been properly controlled and administered by the University, which had not adopted the normal procedure of setting up a building sub-committee to process construction throughout: the Treasury has made the establishment of such a committee a condition of a further grant.

Criticizing the Department for not inquiring more closely into the University's arrangements with the consultant engineers and into the system of control over the design and construction work, the Committee of Public Accounts recommends that in future, when Government departments entrust substantial grants to universities for specific projects, they should seek the advice of the University Grants Committee on such matters as definition of contracts, establishment of university sub-committees responsible for executing the projects and any other measures necessary to control and supervize capital expenditure. 